\title{
"The prostate is the sun around which all satellites of urology orbit, except pediatric urology"1
}

\author{
Andrew MacNeily, MD \\ Department of Urologic Sciences, University of British Columbia, Vancouver, BC, Canada
}

Cite as: Can Urol Assoc J 2017;11 (1-2Suppl1):S47. http://dx.doi.org/10.5489/cuaj.4345

See related article on page $\$ 41$.

C anadian geography is vast. As a result, community urologists outside of major urban areas without the luxury of nearby dedicated children's hospitals need to be familiar with and comfortable making decisions regarding children with common inguinoscrotal complaints. As we struggle with the implementation of a competencybased system of residency training, it is clear that there are knowledge domains that are a must (like those in this article) and there are surgical skills that would be nice to have, but sometimes not safe to implement, due to lack of local support. This message cuts across all spheres of urology; prostate-related, pediatric, or otherwise.

A few take home messages I gleaned from this article:

1. Don't order routine ultrasounds for undescended testes, palpable or not. It just wastes resources and delays definitive consultation and management.

2. In the setting of a pediatric testis mass with a normal alpha-fetoprotein (AFP), an attempt at testis-sparing surgery is not oncological heresy.

3. For sure, the hot potato of urology is acute scrotal pain. The majority of boys presenting to the emer- gency room with scrotal pain do not have testicular torsion, but...what if? Selective use of Doppler ultrasound can be helpful, albeit not universally available after-hours. The ability to make a decision is paramount. Interested readers should consult some recent evidence that can help us all make decisions in this anxiety-provoking situation. ${ }^{2}$

This excellent and succinct review by Guerra and Leonard should be required reading for all urologists. In addition, download it and send it along to your referring primary care physicians.

Competing interests: The author reports no competing personal or financial interests.

This paper has been peerreviewed.

\section{References}

1. Leonard MP. Personal communication. Circa 1994

2. Sheth KR, Keays $M$, Grimsby GM, et al. Diagnosing testicular torsion before urological consultation and imaging: Validation of the TWIST score. J Urol 2016;195:1870-6. https://doi.org/10.1016/i. juro.2016.01.101

Correspondence: Dr. Andrew MacNeily, Department of Urologic Sciences, University of British Columbia, Vancouver, BC, Canada; amacneily@cw.bc.ca 